\title{
Exploring Textual Metafunction in Selected Nigerian News Reports: Linguistic Description and Interpretation
}

\author{
Innocent Sourou Koutchadé \\ Département d'Anglais \\ Université d'Abomey-Calavi, République du Bénin
}

\begin{abstract}
This article intends to provide a linguistic analysis of some Nigerian news reports. It is carried out with a view to finding out how news reporters use the language to organize their texts so as to convey their message. The paper adopts the textual meaning approach advanced by Halliday $(1978 ; 1985)$ and detailed by Eggins $(2004)$. Two texts are selected purposely and patterns of Themes and cohesion have been studied. The analyses show that the two texts display high percentage of unmarked topical and textual Themes. Then, both marked Theme and dependent clauses as Themes are less predominant but they are used to draw more attention on some aspects of the message provided. The cohesive analysis has revealed that anaphoric reference chains and features of lexical cohesion have made it easy to understand the meaning conveyed by the two texts. From these analyses, it has been pointed out that the two texts, viewed from their context of production, have accounted for the release of some Chibok girls who were kidnapped by Boko Haram, a terrorist and Islamic group based in the northeastern part of Nigeria, in the year 2014.
\end{abstract}

Keywords: Nigerian news reports, linguistic analysis, textual meaning, Theme, cohesion, Boko Haram, Chibok girls.

\section{INTRODUCTION}

At this very age of communication technology, information is provided via mass media, social media, the internet and many other media. Journalists and news reporters use these means of communication to inform and convey their messages. These reports are judged according to their content and the subject matter discussed. In order to really value these texts, some scholars (Halliday, 1985, Hasan, 1985, Eggins, 1994/2004) suggest that a linguistic analysis is necessary. As observed by Halliday (1985), the application of linguistics to text analyses aims, generally at "understanding the quality of texts: why a text means what it does, and why it is valued as it is" (p. xxx). In this paper, attempts are made to carry out a linguistic analysis of two news reports. The theory upon which the work is hinged is Systemic Functional Linguistics (SFL) developed by Halliday $(1978 ; 1985)$ and elaborated on by Eggins $(1994 ; 2004)$. It is an approach which, as Eggins (2004) claims, views language as functional and organized to produce socio-contextually influenced meanings. Some aspects of textual meanings are studied in the selected texts.

Actually, this article is organized into three sections. The first one deals with the theoretical framework which underlies the study: it provides clarifications in terms of appropriate definitions of the different linguistic features related to textual meaning. The second section focuses on the analysis of the selected texts through the linguistic patterns of Theme and Cohesion. As for section three, it accounts for a discussion of the different findings. 


\section{THEORETICAL FRAMEWORK}

According to Halliday (1985a), a text is structured to make three kinds of meaning simultaneously. These are experiential, interpersonal and textual meanings. These meanings known as metafunction play a very important role in the grammar of the English language. The textual meaning, which is our main focus in this paper, is concerned with the way texts are organized. Halliday (2002) says:

The textual metafunction [...] is the component whose function is specifically that of creating text, of making the difference between language in the abstract and language in use. In order words it is through the semantic option of textual component that language comes to be relevant as distinct from decontextualised language like words listed in a dictionary or sentences in a grammar (p.29)

This is why Eggins (2004), when quoting Halliday (1985) describes the textual meaning as the 'relevance' metafunction and views it as "the level of organisation of the clause which allows the clause to be packaged in ways which makes it effective given its purpose and its context" (p. 298)

The textual element of the clause is made up of two main elements: the structural-generating element which includes the thematic and information systems and the cohesive relations which are reference, substitute-elliptical, conjunctions and lexical cohesive. In this study, a special attention has been put on the thematic and cohesive features.

\section{Thematic systems}

Theme is the element which serves as the starting point for the clause. (Halliday, 1985; Halliday \& Mathiessen, 2004; Eggins , 2004, Bloor \& Bloor, 2004). Halliday (2002) contends that the thematic systems are systems of the clause, and represent the speaker's organization of the clause as a message. The basic structure through which this organization is realized is that of Theme and Rheme, which, in turn, is expressed through the order of the elements: the Theme comes first. Yule (1987) contends that the Theme of a declarative sentence is a noun phrase, that of interrogative is the interrogative word, and that of imperatives the imperative form of the verbs. In that respect, Halliday (1985) identifies three main types of Theme which correspond to the three metafunctions:

- Topical/ideational Theme: It describes what the clause is about or the topic of the clause (Bloor \& Bloor, 2004). Eggins (2004) states that it is an element of the clause to which transitivity can be assigned. Topical Theme can be marked, i.e. atypical or unmarked.

- Interpersonal Theme: it is realized as an interpersonal element because the mood label can be assigned to it.

- Textual Theme: Theme realized by a textual element such as conjunctive adjunct and continuative adjunct.

\section{Cohesion}

Cohesion is another aspect of textual meaning. It refers to the way bits of discourse are related or tied together. Halliday (1985) views cohesion as the non-structural resource for discourse. He says that

In order to construct discourse, we need to be able to establish additional relations within the text [...] relations that may involve elements of any extent, both smaller and larger than clauses, from single words to lengthy passages of texts; and that may hold across gaps of any extent, both within the clause and beyond it, without regard to the nature of whatever intervenes. This cannot be 
achieved by grammatical structure; it depends on a resource of a rather different kinds. (p. 288)

These resources also contribute to the creation of texture in a text and it is the cohesive relation that mostly provides texture. Halliday and Hasan (1976, p.4) quoted by Eggins (2004) contend that:

Cohesion occurs when the INTERPRETATION of some element in the discourse is dependent of that of another. The one PRESSUPOSES the other, in the sense that it cannot be effectively decoded except by recourse to it. When this happens, a relation of cohesion is set up, and the two elements, the presupposing and the presupposed, are thereby at least potentially integrated into a text (original emphasis).

Cohesive ties include reference, ellipsis and substitution, conjunction and lexical cohesion. In this paper, a particular attention is given to some cohesive features such as reference, conjunction and lexical cohesion.

\section{Reference}

According to Bloor and Bloor (2004), a characteristic of cohesive reference is that, on second and subsequent mention, instead of being named, the person or thing referred to may be indicated by means of a pronoun, demonstrative or a comparative. So a participant in a text can be taken as a reference point for something that follows. Halliday (2002) further provides details regarding the different types of reference:

The reference may be exophoric, to some phenomenon located outside the text and in the context of situation; or endophoric, to an element within the text, typically something that has preceded (anaphoric) but sometimes to something that follows (cataphoric)... In a written narrative, all reference can be assumed to be endophoric; but the possibility of exophoric reference appears at one remove in the dialogue that is embedded in a narrative (p. 38, original emphasis)

\section{Conjunction}

It refers to how the writer creates and expresses logical relationships between the parts of a text. Eggins (2004) contends that there are three main types of cohesion including Elaboration (relationship of restatement or clarification, by which one sentence is a re-saying or representation or representation of a previous sentence), extension (a relationship of either addition or variation, enhancement (the ways by which one sentence can develop on the meaning of another)

\section{Lexical cohesion}

It is achieved by the use of vocabulary, by reiteration and by collocation

\section{METHODOLOGY}

As said previously, this study focuses on the analysis of two Nigerian news reports. These texts are taken from online news reports. The first is taken from "The Vanguard" of 16 October 2016, whereas the second is a news report posted October 15, 2016 in "News Source". The two articles are downloaded from the internet. Halliday's (1985) Systemic Functional Linguistic approach of textual meanings is the theoretical background of this study. The two texts are selected purposely because they deal with the same topic: the release of some abducted Chibok girls. First, the Theme analysis is carried out. It consists in identifying the different Themes and studying them through a quantitative and qualitative method. Then, a 
qualitative analysis has emphasized some striking cohesive features, mainly, reference and lexical cohesion.

\section{Theme analysis of text 1}

\section{DATA ANALYSIS}

\section{Theme identification in text1}

This identification is implemented by using the following keys as adapted from Eggins (2004) and used by Koutchadé (2015):

\section{Keys:}

Theme is underlined; Textual Theme: in italics; Interpersonal Theme: in CAPITALS; Unmarked Topical Theme: in bold; Marked Topical: in bold and italics; Dependent clause as Theme: whole clause in bold.

\section{Text1}

1-A source close to the negotiations confided in Sunday Vanguard 2-that unlike the 21 girls, who were freed by the sect, last Thursday, to test government's level of commitment and sincerity, the release of the remaining girls may be based strictly on ransom payment and freedom for no fewer than 16 of Boko Haram commanders by the government. 3- $\underline{\text { The }}$ government, it was learnt, was eager to get the remaining 83 girls, reportedly held by a top leader of the sect in an undisclosed location in the North East. 4- 0 f the 219 girls still missing, a source said 5-that only 104 were left in the captivity of the sect 6-while the rest had long been married off by top commanders 7-and (the rest) converted to Islam. 8-"The truth is 9that those Chibok girls are now Boko Haram members, 10-(those Chibok girls) having married the sect members 11-and those Chibok girls become radicalized," 12-the source said. 13-"The remaining 83 girls are with a top leader of Boko Haram 14-and those are the only ones 15-we are going to work for their release in the next phase of our negotiations 16which starts immediately. "17-The others had since become Boko Haram members, 18-(the others) having been married off 19-and (the others) radicalised into Boko Haram 20-as soon as they were captured over two years ago". 21-But Sunday Vanguard learnt 22-that the representatives of the sect, [[who are meeting with a Federal Government team]], might insist on payment upfront of huge cash by government 23-before (the representatives of the sect) freeing the captives 24-"I think 25-the guys are settled on the idea 26-that the cash must come ahead of the release 27-since they had proved to government 28-that they are reliable by releasing the 21 girls, last week, without many conditions attached", 29-the source stated. 30-Asked if the sect leaders were unsure of government's sincerity to keep its own side of the bargain, the source said 31-that the representatives of Boko Haram had also shown 32-that they have confidence in government. 33-It was learnt 34-that the lingering challenge [[in getting back all the girls]] arose from the fact that 35-while some of them are with a faction loyal to Benawhi, 36-the rest are being kept by the group loyal to Abubakar Shekau. 37-But one of the negotiators believed 38-the remaining 83 girls would be freed 39-if a meaningful deal is struck between the sect and the Federal Government. 40Meanwhile, the Office of the National Security Adviser (ONSA) has said 41-that threats posed by terrorism and violent extremism in parts of Nigeria have not only stretched law enforcement agencies 42-but the Office of the National Security Adviser (ONSA) have also exposed the gap in the nation's capacity to deal with asymmetric warfare." 43-Coordinator of the National Counter-Terrorism Center (CTC) in ONSA, Commodore Yem Musa, [[who stated this in at a one-day 'Strategic Communication Analytical Technique Exercise' in Abuja]], said 44-that violent extremist groups were more adapted to using strategic communication than government. 45-" Through this exercise, we will explore 46-how strategic 
communication must be a first order capability in the armed forces, law enforcement and intelligence agencies as well as strategic MDAs of government", 47-Musa said. 48-Musa explained 49-that the nature of asymmetric warfare and the liberalization of information access through the social media have made it imperative for any state actor serious about its national security to develop efficient and effective use of Strategic Communication. 50-He noted 51-that the threat from terrorists, insurgent groups and other non-state actors in the country, has called for enhanced capacity and holistic measures to deal with the emerging security challenges. 52-The CTC boss however, expressed regret 53-that whereas the nonstate actors in the country have perfected effective use of the social media, Information and Communication Technology (ICT) to deadly effect, 54-the government is still playing a catch-

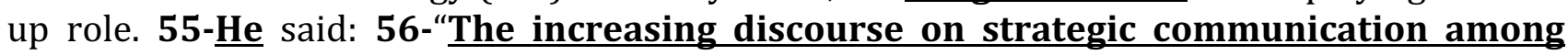
stakeholders in Nigeria can be linked to the growing body of research on, and practice of counter-terrorism laws, policies and strategy. 57-This, too, is as a result of a new kind of threat hitherto unknown to us. 58-Musa informed stakeholders at the exercise 59-that "strategic communication is a crucial and relevant tool for counter terrorism and counter insurgency 60-and strategic communication permeates all governance structures and enhance national security and well-being". 61-At the end of the exercise, participants agreed on the need to develop a common lexicon on strategic communication across MDAs in Nigeria. 62-Remaining captives must be free - 63-UN Secretary General in a related development, United Nations Secretary General, Mr. Ban Ki-moon, yesterday commended the efforts of the Federal Government 64-that paid off with the release of the 21 Chibok girls on Thursday. 65- $\underline{\mathbf{A}}$ statement from the UN Secretariat in New York stated 66-that the Secretary-General also called on the international community to assist Nigeria in securing the release of the remaining girls from Boko Haram's grip. 67-The statement read: 68-"The Secretary-General welcomes the reported release of 21 Chibok schoolgirls, following more than two years of captivity. 69"He remains deeply concerned about the safety and well-being of the remaining schoolgirls and other victims of abduction by Boko Haram, 70-who are still in captivity. 71-"The Secretary-General urges the international community to continue supporting the government of Nigeria in its efforts to secure their release, rehabilitation and reintegration. 72-“ $\underline{\text { He calls for }}$ increased efforts to ensure additional humanitarian access in the north-east of Nigeria, 73-and (he) reiterates the continued commitment of the United Nations in this regard. 74-"The Special Representative of the Secretary-General for West Africa and the Sahel, in his capacity as High Representative for Nigeria, continues to engage with the Nigerian authorities and international partners on this matter."

VANGUARD OCTOBER, 16, 2016 www.vanguardngr.com/author/adekunle.

\section{Analysis of Theme patterns in Text1}

The different Theme identified in this text have been counted and their percentages have been calculated and summed up in table 1 below

Table 1: Theme-types statistics in text1

\begin{tabular}{|l|l|l|}
\hline Theme-types & Number & $\begin{array}{l}\text { Percentag } \\
\text { e }\end{array}$ \\
\hline Unmarked topical & 62 & $83.78 \%$ \\
\hline Marked topical & 06 & $08.10 \%$ \\
\hline Textual & 31 & $41.89 \%$ \\
\hline Interpersonal & 00 & $00 \%$ \\
\hline $\begin{array}{l}\text { Dependent clause } \\
\text { as Theme }\end{array}$ & 02 & $02.78 \%$ \\
\hline Total/ Clauses & 74 & $100 \%$ \\
\hline
\end{tabular}


From the table above, one can infer that unmarked topical Themes are mostly used in the text. They rank first: 62 (83. 78\%), showing that the number of unmarked Theme outweighs, largely, the number of other Themes. These unmarked topical Themes play the subject role in their related clause and the transitivity role can be assigned to them (Eggins, 2004). Their use implies that the text is meant to describe concrete, movement, psychological, as well as physiological actions. Actually, the text gives account of the conditions under which 83 more Chibok girls, apart from the 21 that have been previously released, will be freed. This accounts for the fact that members of the sect are used as topical Themes in $(22,23,25,27,31,32,37$, 44). Another Thematised elements include "the remaining 83 girls" and their related pronouns in $(13,17,19)$, Musa, the coordinator of the National Counter-Terrorism Center (CTC) in ONSA, in $(47,48,50,58))$. This shows that members of Boko Haram have negotiated the conditions under which other abducted girls, 83 in number, can be released by members of the sect. In addition, the phrase: "The united nation general secretary" is also used as topical Theme in $(63,65,66,68,71)$ to show that practical decisions have been taken and words of encouragements have been expressed by the United Nations regarding the release of these abducted girls. These various topical elements have played the transitivity roles including: actors, senser, behaver, sayer, attributes (Eggins, 2004).

Textual Themes rank second in this text: 31 (41. 89\%). As pointed out by Halliday (2002), they are either continuative, conjunctive or structural (either paratactic or hypotactic conjunctions). In this text, one can notice that continuatives are non-existent. Various conjunctive elements are used as Themes. The most predominant structural element used in the text is "that" in $(2,5$, $9,22,26,28,31,32,34,41,44,49,51,53,59,66$ ) which is used to link dependent clauses together. Other hypotactic conjunctive elements identified are before, as soon as, since, while, if and how which are exemplified in $(6,20,23,27,35,39)$. In addition, some conjunctive elements used in thematic positions are coordinators which are used to express a paratactic relationship between clauses. For instance, "and" is used in $(7,11,14,19,73)$ to express the relationship of addition whereas "but" is employed in $(21,37,42)$ to mark adversative addition (Halliday, 1985).

Marked Themes rank third in this text 06 (08. 10\%). These are foregrounded elements which are thematised to provide prominence to some aspect of the passage of the text in $(2,3,4,30$, 45, 61). In (2), the phrase: "unlike the 21 girls, who were freed by the sect, last Thursday, to test government's level of commitment and sincerity" is used to inform readers about the conditions under which the abducted girls have been freed, their exact number and the government intervention into the matter. This is the reason why in (3), the phrase "the government" is used in Thematic marked position to show how the Nigerian government is actively concerned with developing strategies to free the girls. Moreover, the text emphasized the number of the girls kidnapped, which accounts for the use of "of the 219 girls still missing" in thematic position in (4), showing that efforts are being made to find them. Likewise, in (30), the marked Theme stresses the negotiation between the sect and the government whereas in (45 and 61) the writer has insisted on the strategic communication, a relevant tool to counter terrorism.

Moreover, apart from marked Themes, 02 (02.18\%) dependent clauses as Themes are used in the text and occur in $(35,53)$. These are marked Themes which indicate that the writer aims at expressing contingency, constraining the proposition expressed in the dominant clauses (Bloor and Bloor, 2004 cited in Koutchade, 2015a). They are used in the text to show where the girls are kept after being kidnapped and to stress the fact that Boko Haram members have taken advantage of the social media more than the government. 
Interpersonal Themes are non-existent in this text, which means that the writer has not expressed his attitudes and judgments while relating the events on the one hand, and he has not made use of mood or modality or modal adjuncts or auxiliary verbs in the thematic position, on the other.

\section{Theme analysis of text 2}

\section{Theme identification in text 2}

Using the suggested keys of the previous section, the different Themes that occur in the second text have been identified in the text below.

\section{Text 2}

1-Parents of the 21 Chibok schoolgirls [[who were released on Thursday]] were on their way to Abuja last night after an all day journey from Borno State for a reunion with their long missing daughters. 2- Fathers and mothers are expected to set their eyes on their beloved ones for the first time in over two years in a re-union 3-that is bound to be highly emotional. 4The girls are currently in the custody of the Department of State Security (DSS) 5-which, along with the Swiss Government and Maiduguri lawyer Mustapha Zanna, negotiated their release from Boko Haram. 6-A medical team has been attending to them since their return from custody. 7-All the girls have spoken with their parents on the phone since their arrival in Abuja. 8-But the Department of State Security Services (DSS) has restricted access to the girls. 9-Senate Leader, Senator Ali Ndume [[who is from Borno State]] visited the girls yesterday 10-and (Senate Leader, Senator Ali Ndume) broke down in tears on sighting them. 11-The girls consoled him. 12-The girls appeared far better than 13- they were 14-when they arrived in Abuja on Thursday. 15-There was evidence of joy all over them. 16-And they sang, 17-(they) praising God 18-and (they) thanking Ndume.,"Allah Ya kawo baba mu, mugode Allah"19-(God has brought our father, we praise the Almighty God) was the theme of their song. 20-A top source told The Nation 21-that logistics delayed the parents/girls reunion. 22-"Due to logistics, the 21 girls have not met with their parents. 23-

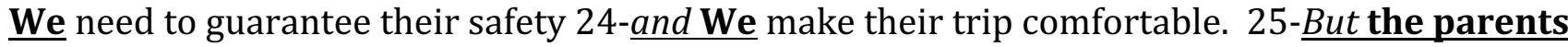
are in transit (as at 8pm on Saturday) 26-and by Sunday they will reunite with their children," 27-the source said "28-So far, all the girls have spoken with their parents and relations on the phone. 29-They are in touch and eager to meet with them. 30-"The DSS has however restricted access to the girls for strategic reasons. 31-We do not want to make them vulnerable again 32-since they are undergoing rehabilitation." 33-Senate Leader Ndume was allowed to meet with the girls between 3pm and 4pm yesterday. 34-Another source said: 35-"Upon

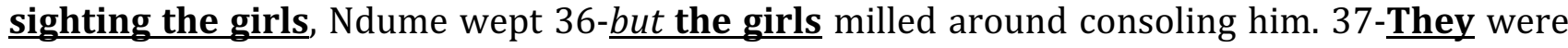
in high spirit. 38-Speaking with our correspondent last night, Ndume confirmed the audience with the girls. 39-He said: 40-"I was with them for an hour 41-and I observed 42- that their recovery is rapid. 43-They are looking forward to meeting their parents on Sunday

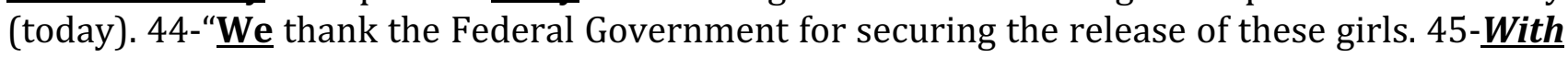
this development, there is bright light at the end of the tunnel." 46-Responding to a question, Ndume said: 47-" There was no sign 48-that the girls were molested 49-or the girls forced to abandon Christianity in captivity. 50-Gloria, [[who is their leader]] led the Christian prayer session during my visit. 51-She offered the prayer in a moving manner 52-and I said 53-you are qualified to be a pastor.' 54-"They were in good spirit,55- the medical experts, psychologists and other social workers have done a good job.56-I am optimistic 57-that they will recover faster." 58-A member of the Chibok community [[who does not want to be named]] said last night 59-that a thanksgiving service will be held for the safe return of the girls in an undisclosed church in Abuja today. 60-Meanwhile, the Defence Headquarters yesterday said 61-the release of the girls has not caused disquiet in the military. 62-It also said 63-the operation in the North-East against Boko Haram insurgents will continue. 64- 
The DHQ made the clarifications in a statement by the Acting Director Defence Information Brig.-Gen. Rabe Abubakar. 65-He said: 66-“The Defence Headquarters' attention has been drawn to an online 67-and newspaper publication insinuating 68-that there is a mixed feeling among Nigerian military ranks and files as a result of the recent release of some Chibok girls. 69-"The military wishes to state unequivocally 70-that the Armed Forces will continue to work closely with all our sister security agencies to achieve more feat in this direction. 71"The military also want to debunk the baseless and unfounded story 72-that there is disquiet in the military over the condition of release of the girls. 73-"The Nigerian Armed Forces and other security agencies are one working together to finish the war on terror and other criminalities 74-which can be done covertly or overtly. 75-The most important thing is achieving our strategic objective. 76-"The DHQ has said before 77-that negotiation with the terrorists or any other group rests purely on our respected political leaders. 78-The military operations to rid our land of terrorists continue. 79-"It is important to state 80that not all information is meant for public consumption due to processes 81-which is purely political. 82- More so, the ongoing military operation is making unprecedented progress with the rescue of many captives held by the terrorists. 83-The general public should discountenance with this baseless and misleading story. 84-"While the Armed Forces hold the media veritable partner, it urges the media to be mindful and clarify with the military 85when reporting security and defence issues bothering on sensitive national matters of this nature."

\section{Analysis of Theme patterns in text2}

Basing on the Theme identification above, each category of Theme has been counted and the table below provides the summary of their statistics.

Table 2: Theme-type in text2

\begin{tabular}{|l|l|l|}
\hline Theme-types & Number & Percentage \\
\hline $\begin{array}{l}\text { Unmarked } \\
\text { topical }\end{array}$ & 74 & $87.07 \%$ \\
\hline Marked topical & 06 & $07.09 \%$ \\
\hline Textual & 28 & $32.94 \%$ \\
\hline Interpersonal & 00 & 00 \\
\hline $\begin{array}{l}\text { Dependent } \\
\text { clause as } \\
\text { Themes }\end{array}$ & 02 & $02.35 \%$ \\
\hline Total/ Clause & 85 & $100 \%$ \\
\hline
\end{tabular}

As can be noticed in table 2, topical unmarked Themes rank first in this text: 74 (87.07\%). This implies that the first element that plays a transitivity role occurs in clauses and they help pointing out the field of this text. Indeed, this text focuses of the first meeting of Chibok girls with their parents after they have been released by the terrorists. These girls have been detained for over two years by Boko Haram members. In that respect, these Chibock girls (refered to as 'girls', "they") are used in thematic position in $(4,7,11,12,13,14,28,48,49,54)$, whereas "parents of the girls" are used in $(1,2,25)$. Similarly, Senate leader, Senator Ali, anaphorically referred to as "I", "he" or "we" in $(9,10,33,39,40,41,44,52,56)$, is used as topical Theme because, as the highest authority of the State, he was permitted to meet with the girls. Likewise, the Defense Headquarters has also been used as topical unmarked Theme in $(64,65,66,69,70,71,73,76)$. This shows that security agencies are at alert every time, not only to ensure that the security of the girls is guaranteed, but also to ensure that the 
continuous effort to maintain peace, security through the strategies to fight terrorism in Nigeria, is guaranteed. These unmarked thematic elements which recur in the text along with other elements are used in this text to point out the subject matter of the text.

Textual themes are also important in the text. They are 28 in number and represent $38.14 \%$ of the total. Even though they do not express any interpersonal or experiential meaning, they play very important roles through their cohesive work and by relating clauses to their context (Eggins, 2004). Just like text1, this text does not display any use of continuity adjuncts as there is no feature of spoken dialogue in any part of it. The text displays an important number of tactic conjunctions which are used to bind clauses together within clause complexes. For instance, "that" occurs in $(21,42,48,57,68,70,72,77,80)$ to link hypotactic clause complexes together. In addition, "since, when, while" are also used as tactic conjunctions in $(14,32,84)$ to link clauses in hypotactic form. Some cohesive conjunctions such as "so far" and "more so" are used in thematic position even though they link sentences together. Finally, some tactic conjunctions are used to link clauses paratactically. These are coordinators such as "and" in $(10,16,18,24,26,41,52,67)$ which displays the relationship of addition, "but" in $(8,25,36)$, showing adversative addition (Halliday, 1985a) and "or" in (49) which expresses the relationship of variation.

Marked topical Themes rank third: 06 (07.09\%), showing that some atypical events have been described and the writer has insisted on some particular details regarding the conditions under which the girls can meet their parents. They occur in $(22,26,38,45,46)$. In (22), the writer of the article has insisted on the fact that certain conditions must be met before the rescued girls can meet their parents, whereas in (26), the marked topical Theme is used to specify the day the girls will go back to their parents. In addition, the senate leader has met with the girls and he is happy to see them in good health. Therefore, he voluntarily speaks to the journalists to inform them about the new development regarding the situation. This is the reason why marked Themes have been used in $(38,45,46)$. Finally, dependent clauses as Themes are less predominant. Two cases are noticed in the text.

The structural element of textual meaning being studied, we now focus on some aspects of cohesive features in the text.

\section{Analysis of cohesion}

The study of cohesive features has lead us to deal with the most striking ones. They include reference and lexical cohesion.

\section{Reference}

The study of reference requires the identification of reference types in the text. Here indeed, sentences are taken into account and the anaphoric types of references, the most striking ones, are pointed out in the chains below:

\section{Chain 1: Girls}

(1)21girls - the remaining girls- (2) the remaining 83 girls- (3) the 219 girls- only 104- the rest -(4) those Chibok girls- (5) the remaining 83 girls-those- their release-(6) the others-(7) they(8) the 21 girls- (10) all the girls- some of them- the rest- (11) the remaining girls- (22) remaining captives- 21 Chibok girls- (24) the remaining girls- (25) 21 Chibok school girls- (26) the remaining school girls- (27) their release.

\section{Chain 2: Boko Haram members}

(1) No fewer than (P) - Boko Haram commanders - (2) top leader of the sect- (3) top commanders- (4) Boko Haram members- (5) a top leader of Boko Haram- (6) Boko Haram 
members- (7) the representative of the sect- (8) the guys- they-they-(9)- the sect leaders- the representative of Boko Haram- they- (10) a faction loyal to Benawhi- the group loyal to Abubakar Shekahu- (11) one of the negotiators- the sect- (12) terrorism and violent extremism- (14) violent extremist groups- (16) terrorists, insurgent groups- (20) terrorism (23) Boko Haram (25) Boko Haram.

\section{Chain 3: the government}

(1)Government's level of commitment and sincerity- the government- (2) the government-(7) a Federal Government team- government- (8) government- (10) government- (12) the federal government- (13) government- (14) government- (17) the government- (22) the Federal Government- (26) the government.

\section{Chain4: Office of the National Security}

(12) the Office of the National Security Adviser (ONSA) - the Office of the National Security Adviser (ONSA)- (13) Coordinator of the National Counter- Terrorism Center (CTC) in ONSA Commodore Yem Musa -(14) Musa- (15)- Musa - (16) he- (17)- the CTC boss-(18)- He- (20) Musa.

\section{Chain 5: UN Secretary General}

(22) UN Secretary General- (23) the UN secretariat in the New-York- the Secretary General(25) He- (26) the Secretary General-(27) He-the United Nation.

The above ties, as said earlier are anaphoric and all the selected ties involve human participants. As a matter of fact, the first item around which the reference chain is built is the exophoric reference: "21 girls". These are the girls that have been released by the terrorist Boko Haram group. The chain is organized in such a way that the reader is not only informed of the number of those released but he/she also knows the total number of the girls that have been kidnapped, their destination, and the number of those that will be freed very soon. The possessive reference "their release" shows the concern about the remaining 83 girls who are yet to be freed.

The most dominant reference chain is "Boko Haram members". They represent the major participants as they span the whole text. They kidnapped the Chibok girls and kept them in their custody. In order to get some of these girls released after most military and futile intervention, the Nigerian government has resorted to negotiations with some of the representative of the sect. The organization of the reference items shows that most of them are endophoric i.e., they are retrieved from within the text.

Similarly, the third chain which focuses on "the government" creates cohesion with the second one as the government is the political body which has entered into negotiation with Boko Haram representatives to discuss the release of the girls. The two protagonists are trying to play their part in order to come to that agreement. After the use of armed forces for almost two years, the idea of negotiations has been initiated by the government. The comparative reference "no fewer than 16" is used to indicate the number of members of terrorist groups that should be released added to the ransom payment the government has to make.

Moreover, the fourth chain begins with the exophoric reference "the Office of the National Security Adviser (ONSA)". In the context of the event narrated, this service is in charge of the general security of the country. It mainly aims at developing strategies to guarantee security in the whole country. One of the departments is the National Counter-Terrorism Center which 
has been created to challenge Terrorism and violent extremism. The use of proper noun "Musa" and the anaphoric reference shows the concern of the country about the security issue.

Finally, chain 5 concerns "UN Secretary General". This reference chain indicates that the issue of abducted school girls in Nigeria has attracted the attention of the whole world and the United Nation cannot but show her concern about it since it is the result of the development of extremism and terrorism.

\section{Reference in text 2}

\section{The study of reference in text 2}

Just like in text1, the study of reference types has led us to design the different chains below:

\section{Chain 1: Chibok girls}

(1)21 Chibok school girls-their way- daughters- (2) beloved ones- (3)-the girls- their release(4) them- their return-(5) all the girls- their parents-their arrival-(6) the girls-them (7) the girls-(8) the girls-they-they-(9) them-(10) they- (11) they-(12) our father- their-(13) girls(14)their-their trip- (15) the girls-their parents- (16) they- (17) the girls- (18) they- (19) the girls- (21) the girls- the girls- (22) they- (23) the girls- (24) them- their recovery- (25) they their parents-(26) the girls- (28) the girls- the girls- (29) Gloria- (30) she- you- (31) they- (33) they- (33) the girls- (35) the girls-

\section{Chain 2: Parents of the Chibok girls}

(1) Parents of the 21 Chibok schoolgirls- their way- their long missing daughters- (2) Fathers and mothers- (4)-their parents-(13) the parents- (14)-their parents-(15) the parents-they-(16) their- (17) they-(24) their parents

\section{Chain3: Senator Ali Ndume}

(6) Senator leader Senator Ali Ndume-(7) him- (19) Senate leader Ndume- (21) Ndume- (22)him-(23) Ndume- (24) He -I- I-(25) we - (26) Ndume- (28)-I- (30) I-

\section{Chain 4: Department of state security}

(6) Department of State Security Services (DSS)-(18)- the DSS- (34) the Defence Headquartersmilitary-(36) the DHQ-Acting Director Defence Information-(37) he-the Defence HeadquartersNigerian military-(38) the military-the Armed Forces- sister security agencies-(39) the military-the military- (40) the Nigerian Armed Forces and other security agencies-(42) the DHQ-(43) the military operations- (46) the ongoing military operation- (48)-Armed Forcesmilitary.

As can be noticed, these chains are mostly concerned with people. The two longest chains include: "the Chibok girls" and the "Department of state security". Just like text1, the first chain focuses on the "Chibok girls". These girls, as said earlier have been released after a certain number of negotiations with Boko Haram members. Here indeed, the reference items "their trip" and "their parents" are meant to inform readers about the fact that they were taken to Borno to meet with their parents. The second chain entitled "parents of Chibok girls" is also linked to the first as it deals with the parents of the released girls. The possessive reference items are used to point out the relationship between the girls and their parents and the atmosphere of joy that has prevailed when they met. The numerous reference ties are retrieved anaphorically. The third chain "Senator Ali Ndume" also facilitates the understanding of the text as it includes the most important human participant in the text.

Actually, the use of the reference ties contributes to the understanding of the way the whole country, i.e., Nigeria, is more concerned with the fate of the abducted girls and this is the 
reason why the Senate leader Ali Ndume has met with them. The anaphoric references "I", "we" are used to show how he has taken part in the story narrated. The last chain focuses on the "Department of State Security" which includes the Nigerian Armed Forces and other security agencies. Actually, the issue of insurgency and terrorism has become a challenge to the Department of State Security. Police officers and armed forces have been trying their best to eradicate insecurity and terrorism. The chain is so dense and includes services and people working under this department to maintain peace and security in the whole country. This department has been in great demand because of the insurgency and the terrorist group. Consequently, they are always at alert and ready to intervene since their main concern is to ensure that the whole country become free from the terrorist attack.

As pointed out by Eggins (2004), the combination of reference ties that spans the length of the whole text as well as the density of ties and their endophoric retrieval together add up to create highly cohesive, self-contained text.

\section{Lexical cohesive features}

As said earlier, the choice of lexical items also contributes to achieve cohesion in texts. Various lexical items are used in the selected texts. In fact, the most frequent ones include repetition. In the first text, the item "girls", which is synonymous with "the captives", is repeatedly used, as the text has not only provided information about the released ones but the number of those that have been kidnapped by Boko Haram group. This is why the items "Boko Haram" reiterate in the text. More importantly, these items are synonymous with "the sect". Similarly, the item "government", synonymous with "Nigeria" is used repetitively in the text. Likewise, the items "Secretary General" are repeated in this text to show that the United Nation is also concerned about the released of the Chibok girls.

Similarly, in text 2, the item "girls" has been used as the text mostly focuses on their released. More importantly, they express a superordinate relationship with the item "parents", repeatedly used in this text and which is synonymous with "fathers and mothers". The topic of the text is illustrative through the use of these items. Parents of the released girls have met for the first time after having being kidnapped for more than two years. In addition, the item "Ndume" is also repeated. Ndume is the Senate leader who has been given the opportunity to meet with the girls. Another important repeated item is "the military", synonym of "the Armed Forces". More importantly is that in the context of the text, the item "Defence Headquarters" includes the Armed Forces and the military; so it stands in superordinate relationship with Armed Forces and military. The use of these items implies that the issue of security of the whole country has been the concern of the whole country since the advent of the insurgency and terrorist group. Thus, lexical cohesive features are used to realize cohesion and contribute to the coherence of the text.

\section{DISCUSSION OF FINDINGS}

This study has aimed at highlighting the linguistic features that encode textual meaning components in the selected texts. Through the above analyses, the findings reveal, first, the way clauses are hanged together to convey their messages. This is specifically carried out through the thematic organization of the selected texts. As pointed out by Halliday (1895, p. 67), "the thematic organization of the clauses (and clause complexes, where relevant) expresses, and so reveals, the method of development of the text". In the first text, one can notice the way Themes are distributed: Unmarked topical Themes: 62 (83.78\%), marked topical: 06 (08.10\%), textual Theme: 31 (41.89\%), dependent clauses as Theme: 02 (02. 78\%). Actually the writer of this text has made use of unmarked topical Themes to show that the text is mostly concerned 
with actions and events. The most predominant topical Themes are mostly nominal groups referring to specific individual such as "the representatives of the sect", "the guys", "the remaining 83 girls", "remaining captives", "the Secretary General”, etc. Very few pronouns such as "he" "they" and proper nouns are used as topical Themes in the text. The unmarked topical Themes as well as dependent clauses as Themes are used to point out the way striking elements of the text are foregrounded to show that the writer has described atypical events in the text. Textual Themes, which rank second after topical Themes, are all conjunctives which link clauses together either paractactically or hypotactically. Their use is meant to account for the way messages are conveyed in a cohesive and coherent way.

As for the second text, Themes are organized in a similar way: unmarked topical Themes 74 (87.07\%), marked topical Themes: 06 (07.09\%), textual Themes: 28 (32.94\%), dependent clauses as Themes 02 (02. 35\%). Actually, topical unmarked Themes in this text show that human being are used in Thematic position and they include nominal groups such as "parents of the 21 Chibok girls", "fathers and mothers", "the girls", "the military", etc. as well as pronouns such as "they", "he", "I" , showing that this text, like the first one, is about actions and events. Textual Themes, which come after topical Themes, are all conjunctives. No continuity adjunct is used in the text, whereas marked Themes and dependent clauses as Themes are foregrounded to figure out some prominent events in the text. Actually, the Rhematic part provides details regarding the messages given.

As regards features of cohesion, the findings reveal that the two texts show instances of cohesive chains which combine features of lexical repetition and reference. These various chains are tied together and built around the main topic dealt with in the two texts. Viewed in their situational context, the two texts account for the release of Chibok girls. In fact, on 14th April 2014, over 200 girls were kidnapped by Boko Haram insurgents from their school in Chibok, Borno State. This event has become a major concern not only for parents of victims but also for the whole country as well as the the whole world. For several months, the release of these girls from the hand of these terrorists groups has become a real challenge for the Nigerian army since all the efforts made to rescue the girls have proved to be useless. The Nigerian government of the then president, Gooodluck Jonathan was really criticized and this was even part of the reason why the opposition party won the presidential election and Buhari has become the president of Nigeria since 2015. News reporters keep informing the audience on every development of the issue and when Boko Haram release 83 Chibok girls, this situation has attracted a lot of attention and various pieces of information are released by news reporters to inform the audience about the development of events.

\section{CONCLUSION}

Through a linguistic analysis, this study has surveyed the language of the two news reports. From the analysis of textual meaning, it has been easier to deduce the mode of discourse in the two texts. Basing on Eggins (2004), mode refers to the role language is playing in an interaction; it is associated with the textual meaning. So, the two texts present situations where language is used to recount experiences; there is no immediate feedback between the two writers and readers. In addition, although there are features of grammatical simplicity, these texts are written-to-be read with high interpersonal and experiential distance. The study of the two news reports, through the framework of systemic functional linguistics and specifically the contextualized textual metafunction, has revealed that meanings about the release of Chibok girls, the Nigerian government's efforts to negotiate their release, the meeting of the girls with their parents and the effort of Nigerian armed forces to counter terrorism, are expressed in the selected texts. 


\section{References}

Bloor, T. \& Bloor, M. (2004). The Functional Analysis of English: a Hallidayan Approach. (2 ${ }^{\text {nd }}$ ed.) London: Edward Arnold.

Boko Haram sets conditions to free 83 more Chibok girls (16 October, 2016)- Vanguard News. Retrieved (30 October, 2016) from: Vanguardngr.com

Brown, G. \& Yule, G. (1983). Discourse Analysis. Cambridge: Cambridge University Press.

Chibok girls reunite with families (15 October, 2016). Retrieved (30 October, 2016) from:

http://uncova.com/chibok-girls-reunite-with-families

Eggins, S. (1994). An Introduction to Systemic Functional Linguistics. London: Pinter Publishers.

Halliday, M. A. K. (1973). Explorations in the Functions of Language. London: Edward Arnold.

Halliday, M.A.K. (1978). Language as a Social Semiotic: The Social Interpretation of Language and Meaning. London: Arnold.

Halliday, M. A. K. (1985). Introduction to Functional Grammar. London: Edward Arnold.

Halliday, M. A. K. (2002). Linguistic Studies of Text and Discourse. Collected Works of Michael Halliday, Vol. 2. Edited by J. J. Webster. London and New York: Continuum.

Halliday, M. A. K., \& Hasan, R. (1976). Cohesion in English. London: Longman Group.

Halliday, M. A. K. \& Hasan, R. (1985). Language, Context, and Text: Aspects of Language in a Social-semiotic Perspective. Oxford: Oxford University Press.

Halliday, M. A. K. \& Matthiessen, C. (2004). An Introduction to Functional Grammar. (3 ${ }^{\text {rd }}$ ed.). London: Edward Arnold.

Hasan, R. (1985/1989). Linguistics, Language and Verbal Art. Oxford: Oxford University Press.

Koutchadé, I. S. (2015a). Thematic Structure and Foregrounding in Selected Extracts from Adetunji Ogundimu's A Silly Season. International Journal of English and Literature (IJEL), 5(4), 43-54.

Koutchadé, I. S. (2015b). Discourse Analysis of General Muhammadu Buhari's Official Acceptance Speech: A Systemic Functional Perspective. International Journal of English Linguistics, 5(5), 24-36.

http://dx.doi.org/10.5539/ijel.v5n5p24.

Koussouhon, A. L. \& Koutchadé, I. (2013). Aspects of Texture in Wole Soyinka's 'Death in the Dawn' and 'In Memory of Segun Awolowo'. Particip'Action 5(1), 121-135.

Leech, G. N. (1969). A Linguistic Guide to English Poetry. London: Longman.

McGregor, W. (2009). Linguistics: An Introduction. London: Continuum.

Simpson, P. (2004). Stylistics: A Resource Book for Students. London: Routledge.

Xu, S. H. (1985). Study on Theme and Rheme Again. Foreign Language Teaching and Research, 4, 19-25.

Zhu, Y. S. (1995). Thematic Progression and Text Analysis. Foreign Language Teaching and Research, 3, 7-11. 